\title{
ARTISTIC ACTIVITY AMONG THE ELDERLY AS A FORM OF LIFELONG LEARNING, BASED UPON THE OPINIONS OF THE UNIVERSITY OF WROCŁAW'S UNIVERSITY OF THE THIRD AGE HANDICRAFT GROUP MEMBERS
}

\author{
BEATA DZIAtA \\ Faculty of Historical and Pedagogical Sciences \\ University of Wrocław \\ Ul. Dawida 1, 53-311 Wrocław, Poland \\ E-mail address: b_dziala@wp.pl
}

\begin{abstract}
The article deals with the topic of creativity and artistic activity among elderly people in the context of claims related to the idea of lifelong learning. It discusses the phenomenon of creativity and how senior citizens can benefit from it. The artistic activity of people in the age of late adulthood is also discussed in that context. In the last part of the text, theoretical claims are collated with what the artistic groups' elderly members said themselves during a focus group interview.

Key words: third age, late adulthood, creativity, artistic activity, lifelong learning, UTA, older people's education

When raising the matter of elderly people's education, it is important to define the term of late adulthood itself. So far, different scholars that have examined this matter posited different definitions and assumed the period to be starting at various ages. Most frequently a person is considered to enter the stage of late adulthood when they are ca. 60-65 years old. The period itself can be discussed from the angle of chronological, biological and psychological aspects (Straś-Romanowska, 2011). Another viewpoint worth considering is the one presented by Talmage, Lacher, Pstross, Knopf, Burkhart, who claim that the essence of defining one's age lies in the subjectivity of an individual: "Age appears not to be the defining criteria for the third age; thus, the third age may be better defined not by crisis or policy, but by the decision of a person to exist outside of the work activities and careers he or she was immersed in during the second age" (2015, p. 234).
\end{abstract}




\section{LIFELONG LEARNING}

The emergence of the concept of lifelong learning dates back to the beginning of the 1970s. Jarvis defines this idea "as an individual process which continues throughout the whole of life - lifelong learning" (Jarvis, 2004, p. 64-65). It was rooted in the "national efforts to promote lifelong learning societies for people of all ages", „initiatives responding specifically to sharp increases in the percentage of a country's older citizens", , outgrowth of the adult and continuing education movement that gained momentum in the 19th century with the rise of democratic attitudes towards the benefits of education for all - including a nation's older citizens" (Manheimer, 2008, p. 111). Also worth noting are the benefits of lifelong learning, not only for the person but also for the whole community, as they say, Talmage and others: „philosophically, lifelong learning can act as a mechanism for self- and community-betterment and psychological growth" (2015, p. 233).

Older people's education can be backed up by those gerontological studies which are focused on the value of intellectual, emotional and spiritual development - factors that can contribute to the enhancement of one's life quality. What has been made apparent, is that adult people also feel the need to acquire certain skills - ones that can be useful when adapting to situations typical for middle and late adulthood, such as the change of one's social role as a result of retirement, which, in turn, results in having more leisure time and involving in activities such as voluntary work (Manheimer, 2008).

Late adulthood is quite often discussed and examined only from the angle of its negative sides and the limits that it carries. This approach is criticised by Talmage and others, who stress the potentials related to this period of life. Lifelong learning can be the cause of realizing some need or exploration. It also seems worth pointing out that quite often the individuals whose cases were examined in studies stated that they were not even conscious of the possibility of learning. Education of people who are going through the period of late adulthood can result in numerous benefits, such as the sense of joy and satisfaction, increased confidence, better handling of everyday problems, gaining new skills, social engagement, better physical condition and intellectual stimulation that leads to the increase of self-knowledge, the will to support the community in which the senior citizens live, strengthened sense of one's worth, personal and spiritual renewal and finding one's purpose in life (Talmage, Lacher, Pstross, Knopf, \&Burkhart, 2015)

Lifelong learning can be used in different spheres of, especially informal, education (Malewski, 2010). Nevertheless, it is related to the activity of various kinds of institutions. Among them, Universities of the Third Age are a group that can be considered to be implementing the concept of lifelong learning in practice. They fulfil a number of essential functions:

- the educational function, beneficial in terms of acquiring and broadening of one's knowledge, as well as exercising cognitive processes; 
- the affiliative-integrational function, which consists in satisfying the need for belongingness and helps to create interpersonal relationships;

- the expressive function, consisting in satisfying the need for self-expression, which is related to the general activeness, creativity, following one's passion, undertaking charity endeavours, as well as to one's feelings and spiritual life;

- the experiential and exploratory function, related to the opportunity of student internships and conducing academic studies - thanks to the institutions' attendants;

- gerontological prophylaxis - counteraction against the process of growing old too early (Brzezińska, 2014).

With regard to the themes undertaken is worth paying particular attention to the expressive function and the affiliative-integrational function which relate to the functioning of seniors in specific groups and a sense of belonging. On the other hand, through the implementation of expressive function, the elderly create, are creative, are involved in artistic activities and they realize their passions.

\section{CREATIVITY AND ARTISTIC ACTIVITY AMONG THE ELDERLY}

Attempting to define the term of creativity, one can assume, as Hennessey \& Amabile did, that "most researchers and theorists agree that creativity involves the development of a novel product, idea, or problem solution that is of value to the individual and/or the larger social group, psychologists have had great difficulty finding consensus as to definitional components that reach beyond these two criteria of novelty and appropriateness (value)" (Hennesssey, \& Amabile, 2010, p. 572). Still, scholars who aim to redefine this phenomenon and look into it thoroughly, continue to conduct various theoretical analyses and studies (Hennessey, \& Amabile, 2010). Creativity can be examined also in terms of actions that are conducive to development in the sphere of selfreflection, synthesis of ideas and wisdom. Similar conclusions can be drawn from the opinions of individuals in the age of late adulthood (Flood, 2007).

The potential benefits that elderly people can draw from creativity include mental clarity, increased awareness, the possibility to express spiritual experiences that are normally difficult to define, adaptation, aid in dealing with conflicts, improvement of a person's emotional and physical state (Flood, 2007). This type of activity can also have a good effect on the development of skills that are helpful in dealing with problems, improving the adaptive possibilities and allowing one to adjust to everyday problems (Polenick, \& Flora, 2012). As Flood claims, taking into account the numerous benefits of creativity when it is promoted among the elderly, one can easily understand why this matter has so frequently been discussed in different studies and academic projects (Flood, 2007). 
What is more, there emerge new studies that examine the positive influence of creativity on a person's health - in psychophysical terms. Creativity can help to handle stress, anxiety, as well as influence the sense of inner control and satisfaction from life. It has positive effects in terms of dealing with depression and hypochondria. The benefits of creative activity can also be seen in the stimulation of elderly people's involvement and even their reaction time (Flood 2007). Changes in the physiology are equally important. Studies have shown that by stimulating environment, there are new neural networks to enhance neurotransmission. There is also an increase in production of acetylcholine, which modulates the intellectual processes and the memory. We should also pay attention to the processes in the parasympathetic system related with stress. During the creative activity the pulse and heart rate and breathing slows; blood pressure decreases, and the body becomes more relaxed. Moreover, engaging in this type of activity can stimulate the release of endorphins, which have a positive effect on the brain and the immune system (Flood, 2007).

According to Jabłońska, the greatest potential of creative activity and the expansivity of the social one is characteristic for late adulthood. Since adult people need their actions to be directed and organised, they act in a certain order and according to chosen goals. Jabłonska claims that "solidification of the creative potential and of the skill to create" are crucial skills that emerge at that age (2012, p. 93). They can have a good impact on a mature person's sense of purpose in life. They are developed in the course of life experiences and constitute a stimulus for undertaking various types of activities. It can be of great importance for individuals at the age of late adulthood to start some type of artistic activity. Performing it, senior citizens can display their skills and abilities. What is more, it makes them more able to adapt to the reality which they often consider incomprehensible and outdated - more efficiently. Another crucial aspect of the process is that the elderly are given the sense of doing something important for themselves and for others (Jabłońska, 2011).

\section{THE GROUP'S ACTIVITY AND THE STUDY}

The handicraft group functions at the UTA of the University of Wrocław. Once a week the members meet in workshops to produce works of plastic arts and handicraft. The items they create are usually somehow related to tradition and local activity: various kinds of embroidery (cross-stitch, straight stitch, Richelieu, the local embroidery of Wrocław and Kashubia), napkins, doilies, cards for different occasions, traditional Christmas decorations, knitted products, jewelry, stuffed toys, decoupage.

Apart from regular meetings, other types of activity are also important for instance workshops, during which the elderly instruct the participating children on how to create, for instance, Christmas decorations. Another crucial form of the group's activity are the exhibitions organised in places such 
as shopping centres and retirement homes. They offer the group members an opportunity to display their craft to a wider audience and even earn some money from it.

The study took the form of a qualitative research - each participant's case was treated as individual and unique (Konarzewski, 2000). The focus group interview was chosen as a method of obtaining information.

Group members were asked the following questions: what does the group's activity consist of? What types of handicraft would the members consider to be in decline and are they still worth promoting? What do they feel when they are participating in intergenerational workshops? What is the role of creating art in their lives? Does it relate to their previous experience somehow?

As the Peräkylä say, often researchers do not use in the analysis of the material pre-defined protocol but "by reading and rereading their empirical materials, they try to pin down their key themes, and thereby, to draw a picture of the presuppositions and meanings that constitute the cultural world of which the textural material is a specimen" (Peräkylä, 2005, p. 870). The author also describes the methods of data analysis such as: semiotic analysis of narrative, discourse analysis, critical discourse analysis, historical discourse analysis and the categorization analysis of belonging.

According to Silverman analysis of the text, which is also a transcription of the interview, can be analyzed in a qualitative way. It consists in creating some sort of key of the category and categories should be as accurate as possibile. The purpose of such action is to understand which categories are used by participants in social life and how they operate in specific activities (Silverman, 2008).

Research material formed after interviewing focus groups, was analyzed by creating categories and analyze them.

It seems that certain spheres of life are enriched through participation in the artistic group. Firstly, the members said that it is a leisure time activity for them. The role of changes that occur in an individual's life in the age of late adulthood was also emphasised. These are related to the changing social roles, the end of one's professional activity and, thus, to searching for something that could serve as a substitute (Straś-Romanowska, 2011).

Self-development and the possibility to learn were also a very important field for the members. This can be linked to scholars' conclusions concerning the benefits that lifelong learning offers to senior citizens. The group's members also stated that to learn in a group is to educate one another by passing on the knowledge and skills related to a certain field of artistic activity. This process is conducive to the development of interpersonal relationships, which was confirmed by the subjects. These conclusions are quite similar to the ones that can be found in studies dedicated to artistic activity of the elderly. As Jabłońska suggests, human relationships that emerge as an effect of participating in such organised forms of spending time constitute a crucial part of a person's life. Firstly, the participation itself gives senior citizens the possibility to meet and 
spend time with others. Secondly, it becomes a field in which they can learn and practice tolerance, understanding, as well as cooperation in fulfilling a common passion (Jabłońska, 2011).

Positive influence on one's self-esteem, often discussed in various studies, is also linked with the artistic activity (Flood, 2007). The interviewed members emphasized how good it made them feel to be appreciated - that kind of satisfaction, when you've created something and someone says "oh, how pretty it is". This feeling comes as a result of three factors in the group's activity. Firstly, the exhibitions; secondly, the custom of offering the pieces of work to people such as foreigners who visit UTA during various projects; thirdly, the workshops that the elderly organise for children, and which the group members themselves described to be important and valuable: it is very rewarding for us that those children want to learn something. They said that it gave them the possibility to pass on certain important values and truths, such as that one does not need to buy something, if they can make it themselves - even though it requires time, imagination and manual skills. The elderly participants clearly enjoy the fact that children are curious, eager to cooperate and enthusiastic about suggestions they are given. Still, it was emphasised that whether the child will engage in further activity of that kind, depends on the family and the child itself.

In relation to what was said, one can refer to Mead's theory here. The fast pace of changes that are happening in the world leads to the emergence of new types of culture: prefigurative and configurative. This happens as a result of the reversed rules of upbringing and socialisation. Due to changes in culture and civilisation, the knowledge of senior citizens quickly becomes outdated, making it necessary that generations learn from each other - and this is what happens in the case of a configurative culture. In a prefigurative one, younger generations teach the older ones (Mead, 2000). If the elderly are given the opportunity to share their knowledge and experience with others, it can help them to cope with the challenges of modern reality more efficiently, as well as offer them a sense of being needed and appreciated in society. As the subjects of the study put it: the pride of having an opportunity to teach someone something.

The group's members emphasised the therapeutic role of art - that it can help an individual to deal with stress, release tension, give them the possibility to relax and to cope with other problems that influence one's mood. This topic is also discussed in studies about the positive effect of creative activity - on the psychological aspect and biological (Flood, 2007). It is worth paying attention to issues related to stress and coping with it, and the positive role of creative activity in this. Especially in late adulthood in which seniors have to deal with stress of old age. In this age an episodic stress changes in to chronic. This is due to the difficulties of everyday life, the limitations that cause discomfort, also constant changes, which is difficult to deal with (Brzezinska, 2011). The research shows that creativity can be helpful even for patients in clinical trials. Placing the elements of art in intensive care, helps patients to relax, and also leads to the use of a smaller amounts of painkillers (Flood, 2007) 
It is an interesting thing to note that creative activity had no relation to the participants' previous experience - such as their past career. Nevertheless, they could not emphasise it more how important the role of creating art was in their lives at the moment. This was discussed by Talmage and others, where he stressed the role of learning in late adulthood as important in finding the sense and purpose (Talmage, Lacher, Pstross, Knopf, \& Burkhart, 2015).

The participants also shared their thoughts on the uniqueness, originality and quality of the pieces of work that they produced. The pieces of art were described as different, original, and as such that would not be produced by a machine. It was also important for the group members that handicraft is currently going through a revival and that they personally can benefit from that.

Speaking about the characteristics of the group's activity, one can also notice that it helps to revive the practice of crafts that seem to be dying out, such as knitting, ceramics or embroidery. From this point of view, sustaining traditions and passing on the knowledge becomes a value in itself.

\section{CONCLUSIONS}

The reference artistic activity of the elderly to the context of lifelong education, fits this kind of activity in education through art. It can bring many benefits, both in terms of psychological and biological aspects, bringing positive changes in the lives of seniors. Creativity itself is a very favourable type of activity. With regard to the changes in all spheres of life, associated with aging (Straś-Romanowska, 2011), such activities may be particular benefit for seniors. It can help to deal with stress, quietness, as well as in dealing with the problems of everyday life. It can also act as a kind of preventive health care, due to occurring positive changes in the field of physiology.

In relation to the described group there is also a major theme - the tradition, which is continued by seniors, and helping to protect these already endangered crafts. This is another aspect for which artistic activity in old age can be extremely important for the participants.

In summary, the positive effects associated with creative activities are proven in studies, but also felt directly by those taking on creative activities. Accordingly, the maintenance and expansion of offers for senior citizens in this area seems to be very important.

\section{REFERENCES}

1. Brzezińska, M. (2011). Proaktywna starość. Strategie radzenia sobie ze stresem w okresie późnej dorosłości [Proactive old age. Strategies for coping with stress in late adulthood]. Warszawa: Difin SA.

2. Brzezińska, R. (2014). Aktywny wiek senioralny. Z badań nad działalnościa Kujawsko-Dobrzynskiego Uniwersytetu Trzeciego Wieku we Wtocławku [Active age for senior citizens. Research on the activities of the Kujawsko-Dobrzyński University of the Third Age in Wloclawek]. 
Włocławek: WSHE we Włocławku.

3. Flood, M. (2007). Creativity in older adults: a plethora of possibilities. Issues in Mental Health Nursing, 28, 389-411.

4. Hennessey B. A., Amabile T. M. (2010). Creativity. Annual Review of Psychology, 61. 569-598.

5. Jabłońska, M. (2011). Fenomen aktywności artystycznej ludzi w okresie starości [The phenomenon of artistic activity of people in old age]. In: M. Malec (Ed.), Edukacyjne, kulturowe $i$ społeczne konteksty starości [Educational, cultural and social contexts of age] (pp. 57-74). Wrocław: ATUT.

6. Jabłońska, M. (2012). Doświadczanie sztuki jako przestrzeń całożyciowego uczenia się ludzi dorosłych [The experience of art as a space for lifelong learning of adults]. In: W. Jakubowski (Ed.), Kultura jako przestrzeń edukacyjna - wspótczesne obszary uczenia się osób dorostych [Culture as education space - contemporary areas of adult learning] (pp. 93-110). Kraków: Impuls.

7. Konarzewski, K. (2000). Jak uprawiać badania oświatowe. Metodologia praktyczna [How to conduct educational research. Practical methodology]. Warszawa: Wyd. Szkolne i Pedagogiczne S. A.

8. Manheimer, R. J. (2008). Lifelong Learning in Aging Societes. Emerging Paradigmas. Annual Review of Gerontology and Geriatrics, 28, 111-127.

9. Malewski, M. (2010). Od nauczania do uczenia się. O paradygmatycznej zmianie w andragogice [From teaching to learning. The paradigmatic change in andragogy]. Wrocław: Wydawnictwo Naukowe DSW.

10. Mead, M. (2000). Kultura i tożsamość. Studium dystansu międzypokoleniowego [Culture and Commitment: A Study of the Generation Gap]. Warszawa: PWN.

11. Peräkylä, A. (2005). Analyzing Talk and Text. In: Denzin, N. K., Lincoln, Y. S. (Eds.), The SAGE Handbook of Qualitative Research, Third Edition, Thousand Oaks-London-New Delhi: SAGE Publication.

12. Polenick, C. A., Flora, S. R., (2012). Effects of social reinforcement contingent on conventional or unconventional responses on generalized creativity by older adults in residential care. The Psychological Record, 62. 631-644.

13. Silverman, D. (2008). Prowadzenie badań jakościowych [Doing Qualitative Research]. Warszawa: PWN.

14. Straś-Romanowska, M. (2011). Późna dorosłość [Late adulthood]. In: J. Trempała (Ed.), Psychologia rozwoju czlowieka. Podręcznik akademicki [Psychology of human development. Academic handbook] (pp. 326-350). Warszawa: PWN.

15. Talmage, C. A., Lacher, R. G., Pstross, M., Knopf, R. C., Burkhart, K. A. (2015). Captivating Lifelong Learners in the Third Age: Lessons Learned From a University-Based Institute. Adult Education Quarterly, 65(3). 232-249. 